\title{
Kinetics Study of Extracellular Detergent Stable Alkaline Protease from Rhizopus oryzae
}

\author{
Zareena Mushtaq ${ }^{1}$, Muhammad Irfan ${ }^{2 *}$ Muhammad Nadeem $^{2}$, Mammona Naz $^{1}$ and \\ Quratulain Syed ${ }^{2}$ \\ ${ }^{l}$ Institute of Biochemistry and Biotechnology; University of the Punjab; Lahore - Pakistan. ${ }^{2}$ Food and \\ Biotechnology Research Center; PCSIR, Laboratories Complex; Lahore - Pakistan
}

\begin{abstract}
In this study, extracellular alkaline protease was produced from Rhizopus oryzae in submerged fermentation using dairy waste (whey) as a substrate. Fermentation kinetics was studied and various parameters were optimized. The strain produced maximum protease at initial medium $\mathrm{pH}$ of 6.0 medium depth of $26 \mathrm{~mm}$, inoculum size of $2 \%$ at incubation temperature of $35^{\circ} \mathrm{C}$ for $168 \mathrm{~h}$ of fermentation. Alkaline protease was purified to homogeneity by ammonium sulphate fractionation followed by sephadex G-100 chromatography. The molecular mass of alkaline protease was $69 \mathrm{kDa}$ determined by 10\% SDS-PAGE. The optimum $\mathrm{pH}$ and temperature of alkaline protease was 9.0 and $40^{\circ} \mathrm{C}$, respectively. Metal profile of the enzyme showed that the enzyme was non-metallic in nature. The $K_{m}, K_{\text {cat }}, V_{\max }$ and $K_{\text {cat }} / K_{m}$ values of purified protease were $7.0 \mathrm{mg} / \mathrm{mL}, 3.8 \times 10^{2} \mathrm{~S}^{-1}, 54.30 \mu \mathrm{mol} / \mathrm{min}$ and 54.28 $s^{-1} \mathrm{mg}^{-1} . \mathrm{mL}$ respectively, using casein as substrate. The purified alkaline protease had stability with commercial detergents.
\end{abstract}

Key words: Kinetics, Purification, Characterization, Protease, detergent stability, Rhizopus oryzae

\section{INTRODUCTION}

Proteases can be produced from animals, plants and microorganism. On the basis of various economical, technological and ethical issues, microorganisms are considered as the best sources of proteases (Kelly et al. 1976). Proteases, which account for about $60 \%$ of total enzyme market and among the most valuable commercial enzymes, are the single largest class of enzymes occupying a pivotal position due to their wide application in the industrial processes. Microbes serve as the preferred source of proteases because of their rapid growth, limited space required for their cultivation and the ease with which they can be genetically manipulated to generate new enzymes with altered properties (Rao et al. 1998).
Microbial extracellular alkaline proteases are important enzymes and are mainly used in detergents to facilitate the release of proteinaceous stains such as blood, milk, egg and meat.

Microbial proteases contribute $59 \%$ of total enzymes used. Among microorganisms, fungi have now become popular owing their GRAS nature (Generally Recognized as Safe) (Pandey et al. 1997). Fungi elaborate a wider variety of enzymes than bacteria. The fungal proteases are active over a wide $\mathrm{pH}$ range $(\mathrm{pH} 4.0-11.0)$ and exhibit broad substrate specificity. They are also used in the pharmaceuticals medical diagnosis and in the detergent industry as additives (Joo et al. 2003). Fungal alkaline proteases are also used in food protein modification (Rao et al. 1998). Alkaline proteases are an important group of

*Author for correspondence: irfan.biotechnologist@gmail.com 
enzymes and have applications in the leather and detergent industry (Saeki et al. 2007).

Protease production also depends on the morphology of fungal culture. Protease production in filamentous mycelia was greater as compared to pellet form (Papagiani et al. 2002). Extent and pattern of proteases secretion also varies with fungus, age and/or the nature of co supplements (Ashour et al. 1996). Agitation or stirring in submerged fermentation can also directly affect the yield of protease, which influences the cost of enzyme production (Agular et al. 2002). Higher agitation speed to supply proper oxygen damages particularly shear sensitive molds and may result damage of the cells and mycelia network.

Therefore, in the present work static culture technique was used. Surface culture fermentation technique might reduce the capital cost of enzyme production. The aim of the present study was to evaluate Rhizopus oryzae as a producer of alkaline protease using whey as the substrate and to, purify, and characterize the purified enzyme, and its kinetics.

\section{MATERIALS AND METHODS}

\section{Microorganism and maintenance of culture}

Rhizopus oryzae (locally isolated) was obtained from the Department of Botany, University of the Punjab, Lahore, Pakistan. The strain was grown and maintained on potato dextrose agar (PDA) slants. Three-days old fully sporulated slant was used for inoculation.

\section{Substrate and its compositional analysis}

Whey (dairy waste) was used as carbon source obtained from Halla factory, near khayaban-eIqbal Lahore, Pakistan. Total carbohydrate content was measured by phenol-sulphuric acid method (Dubois et al. 1956), total proteins were determined by Lowry method (Lowry et al. 1951), total fat and ash contents were estimated by standard method describe by AOAC (2005).

\section{Submerged fermentation}

Eight different types of media (Table 1) were screened for protease production in submerged fermentation.

Table 1 - Screening of media for alkaline protease production in submerged fermentation.

\begin{tabular}{cccccccc}
\hline Media & $\begin{array}{c}\text { Pure Whey } \\
(\mathbf{m L})\end{array}$ & $\begin{array}{c}\text { Whole Whey } \\
(\mathbf{m L})\end{array}$ & $\begin{array}{c}\text { Yeast extract } \\
(\mathbf{\%}, \mathbf{w} / \mathbf{v})\end{array}$ & $\begin{array}{c}\mathbf{C a C l}_{\mathbf{2}} \\
(\boldsymbol{\%}, \mathbf{w} / \mathbf{v})\end{array}$ & $\begin{array}{c}\mathbf{F e S O}_{\mathbf{4}} \\
(\boldsymbol{\%}, \mathbf{w} / \mathbf{v})\end{array}$ & $\begin{array}{c}\mathbf{M n S O}_{\mathbf{4}} \\
(\boldsymbol{\%}, \mathbf{w} / \mathbf{v})\end{array}$ & $\mathbf{p H}$ \\
\hline 1 & ---- & 100 & --- & ---- & ---- & --- & 5 \\
2 & 100 & --- & --- & --- & -- & 5 \\
3 & ---- & 100 & --- & 0.05 & 0.01 & 0.01 & 5 \\
4 & 100 & ---- & 0.5 & --- & 0.01 & 0.01 & 5 \\
5 & ------ & -- & 5 \\
6 & 100 & 100 & ---- & -- & -- & - & 5 \\
7 & ---- & 100 & 0.5 & 0.05 & 0.01 & 0.01 & 5 \\
8 & 100 & ---- & 0.5 & 0.05 & 0.01 & 0.01 & 5 \\
\hline
\end{tabular}

Various process parameters influencing protease production such as fermentation time (24-196 h), temperature $\left(20-45^{\circ} \mathrm{C}\right)$ initial $\mathrm{pH}$ of growth media (3.0-10.0) growth media depth $(15,26$ and 42.5 $\mathrm{mm})$ and inoculum size $(1-5 \%$, v/v) were optimized for enhanced extracellular alkaline protease production by $R$. oryzae in submerged fermentation.

\section{Analytical methods \\ Biomass estimation}

Fungal biomass was harvested by filtration through pre-weighed whattman filter number 40 $(\mu \mathrm{m})$. The filtrate was used as crude enzyme. Residue after washing with distilled water dried in hot air oven at $100^{\circ} \mathrm{C}$ overnight and used to estimate the cell mass.

\section{Protease assay}

The alkaline protease activity was assayed by Kuntiz (1947) method using casein as substrate at $\mathrm{pH} 9.0$ and $40^{\circ} \mathrm{C}$. After incubation for $30 \mathrm{~min}$, the reaction was stopped using trichloroacetic acid and the amount of librated amino acid was quantified by measuring the absorbance at 280 $\mathrm{nm}$. Protease activity was estimated using tyrosine as standard. One unit of enzyme activity is defined as the amount of enzyme that liberates $1 \mu \mathrm{mol}$ of tyrosine from the substrate per minute per gram of substrate under the assay conditions. Casein agar plates were also used as qualitative assay for protease activity. Diameter of zones was measured using scale. The total protein was estimated using Lowry's method (Lowry et al. 1951) using BSA as standard. 


\section{Purification of alkaline protease}

Extracellular alkaline protease produced from $R$. oryzae was further purified by ammonium sulphate precipitation, followed by sephadex G 100 column chromatography as described by Nadeem et al. (2013). Purity of the enzyme was determined by $10 \%$ SDS-PAGE by the method of Laemmli (1970) and molecular weight was determined by interpretation from a linear semilogarithmic plot of relative mol. weight versus relative mobility.

\section{Characterization of purified protease \\ Effect of pH on enzyme activity and stability}

Effect of $\mathrm{pH}$ on alkaline protease activity was determine by incubating enzyme solution with $1 \%$ substrate (Casein) prepared in buffers of different $\mathrm{pH}$ (citrate buffer 4.0, 5.0; phosphate buffer 6.0, 7.0; Tris- $\mathrm{HCl}$ buffer 8.0, 9.0 and glycine buffer $10.0,11.0)$. After that the protease activity was measured using the standard assay production. To determine $\mathrm{pH}$ stability, the enzyme was incubated in different buffers of $\mathrm{pH}$ values ranging from 6.0 to 11.0 at $40^{\circ} \mathrm{C}$ for $12 \mathrm{~h}$. After incubation, the enzyme activity was measured by standard assay procedure.

\section{Effect of incubation time on enzyme activity}

Effect of incubation time was optimized by incubating the enzyme and substrate mixture for different time periods (5-50 $\mathrm{min})$ using Tris-Hcl ( $\mathrm{pH}$ 9.0).

\section{Effect of temperature on protease activity}

To check the optimum temperature of alkaline protease, the purified enzyme with substrate was incubated at different temperatures $(20,25,30,35$, 40,45 and $50^{\circ} \mathrm{C}$ ). Thermal stability was examined by incubating the purified enzyme at different temperatures $\left(20-50^{\circ} \mathrm{C}\right)$ for $1 \mathrm{~h}$ in a water bath. After that the enzyme activity was measured by standard method.

\section{Kinetic study}

Fermentation kinetic parameters such as $Q_{p}$ (enzyme produced per liter per hour), $\mathrm{Y}_{\mathrm{p} / \mathrm{s}}$ (enzyme produced per gram of substrate consumed), $\mathrm{Y}_{\mathrm{p} / \mathrm{x}}$ (enzyme produced per gram $/ \mathrm{mL}$ cell biomass) and $\mathrm{q}_{\mathrm{p}}$ (enzyme produced per gram of cell biomass produced per hours) were measured as described by Nadeem et al. (2008). Enzyme kinetics was studied by using different concentrations of substrate $\mathrm{K}_{\mathrm{m}}, \mathrm{V}$ max, $\mathrm{K}$ cat, $\mathrm{K}_{\mathrm{m}} / \mathrm{K}_{\text {cat }}$ were calculated by line-weaver Burk plot.

\section{RESULTS AND DISCUSSION}

\section{Proximate analysis of Whey}

The dairy waste (whey) was utilized for extracellular alkaline protease production by $R$. oryzae in submerged fermentation. The substrate had fat and ash content of 1.235 and 69\%, respectively. Total proteins and total carbohydrates were 48.97 and $215.48 \mu \mathrm{g} / \mathrm{mL}$ respectively. Omole et al. (2012) reported that whey contained protein content of $0.36-0.46 \%$, fat content of $0.26 \%$ and ash content ranges from 0.84 to $0.95 \%$. These results demonstrated that the dairy waste (whey) was rich in nutrients and could be potentially used as substrate for microbial fermentation.

\section{Screening of medium}

Eight different media were tested for alkaline protease production in submerged fermentation. Results (Fig. 1) showed that medium 4 gave best enzyme production (137.4 PU/mL) as compared to others. Maximum dry fungal biomass was produced in medium 8 but protease production was very less $(97.6 \mathrm{PU} / \mathrm{mL})$. Hence, medium 4 was used in subsequent study for further optimization. It could be concluded that salts stimulated protease production in the absence of minerals / suspended particles (present in the whey). Ashour et al. (1996) reported that yeast extract in fermentation medium stimulated protease production. Ikram et al. (2004) reported that protease production was greatly affected by optimized and un-optimized solid-state fermentation.

\section{Optimization of process parameters Effect of incubation period}

Any fermentation process is governed by several physical, chemical and biological factors. These factors are fermentation time, $\mathrm{pH}$, temperature and oxygen supply. Nutrient supplements can also effect the enzyme production such as $\mathrm{C}$ and $\mathrm{N}$ sources. To achieve the optimum production of alkaline protease, these factors were optimized during this study. Table 2 shows the effect of fermentation period on alkaline protease production in submerged fermentation. Results showed that enzyme yield with respect to substrate consumption was maximum at $168 \mathrm{~h}$ of fermentation period and the consumption of substrate increased with the time. Talabardon and Yang (2005) demonstrated that optimum enzyme 
was secreted during the stationary phase of growth. Aikat and Bhattaharrya (2000) achieved maximum protease production from $R$. oryzae after nine days of fermentation.

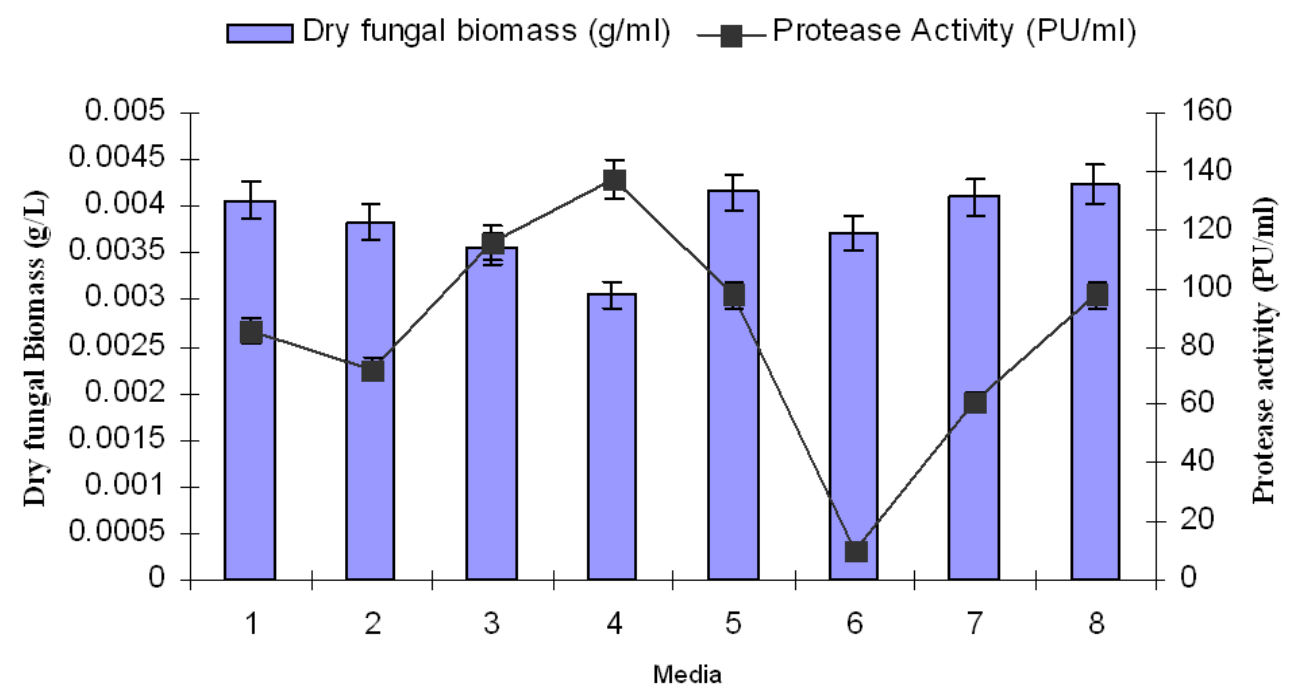

Figure 1 - Screening of different media for alkaline protease production in submerged fermentation.

Table 2 - Effect of time period on alkaline protease production from Rhizopus oryzae in submerged fermentation.

\begin{tabular}{ccccc}
\hline $\begin{array}{c}\text { Time } \\
(\text { Hours })\end{array}$ & $\begin{array}{c}\mathbf{Q}_{\mathbf{p}} \\
(\mathbf{U} / \mathbf{L} / \mathbf{h})\end{array}$ & $\begin{array}{c}\mathbf{Y} \mathbf{p} / \mathbf{s} \\
(\mathbf{U} / \mathbf{g})\end{array}$ & $\begin{array}{c}\mathbf{Y} \mathbf{p} / \mathbf{x} \\
(\mathbf{U} / \mathbf{g})\end{array}$ & $\begin{array}{c}\mathbf{Q}_{\mathbf{s}} \\
(\mathbf{U} / \mathbf{g} / \mathbf{h})\end{array}$ \\
\hline 24 & 4923.4 & 0.26 & 29.01 & 20.89 \\
48 & 4334.5 & 0.31 & 35.00 & 16.67 \\
72 & 3185.2 & 0.34 & 18.72 & 12.6 \\
96 & 3274.6 & 0.39 & 15.64 & 10.12 \\
120 & 3926.7 & 0.45 & 49.87 & 9.22 \\
144 & 4017.8 & 0.49 & 46.38 & 7.50 \\
168 & 4166.9 & 0.57 & 36.5 & 5.98 \\
196 & 3047.8 & 0.48 & 56.19 & 4.80 \\
\hline
\end{tabular}

$\overline{\mathrm{Q}_{\mathrm{p}} ; \text { - Enzyme produced per liter per hour. } \mathrm{Y}_{\mathrm{p} / \mathrm{s}} ;- \text { product yield }}$ (Enzymes produced pergram of substrate consumed.Y $\mathrm{p} / \mathrm{x}_{\mathrm{x}}$;product yield (Enzymes produced per gram of cell biomass). $\mathrm{Q}_{\text {s }}$-Substrate consumed in gram per liter per hour.

\section{Effect of Initial medium pH}

To study the effect of initial medium $\mathrm{pH}$ on alkaline protease production, experiments were conducted in different range of $\mathrm{pH}$ (3.0-7.0) in submerged fermentation. Results (Table 3) revealed that initial medium $\mathrm{pH}$ of 6.0 gave the best enzyme production as compared to others tested $\mathrm{pH}$. The kinetic parameters such as $\mathrm{Q}_{\mathrm{p}}, \mathrm{Y}_{\mathrm{p} / \mathrm{s}}$, $Y_{p / x}$ and $q_{p}$ were also changed with respect to change in the $\mathrm{pH}$ of the medium. Anandan et al (2007) reported initial medium $\mathrm{pH}$ of 9.0 was optimum for protease production by Aspergillus tamari. $R$. oligosporus and $R$. arrhizus produced maximum protease at initial medium $\mathrm{pH}$ of 5.5 and 5.0, respectively (Irfan et al. 2011). $\mathrm{pH}$ of the culture medium also strongly affects many enzymatic processes and transport of various components across the cell membrane (Moon et al. 1991).

Table 3 - Effect of initial medium $\mathrm{pH}$ on alkaline protease production from Rhizopus oryzae in submerged fermentation.

\begin{tabular}{ccccc}
$\begin{array}{c}\text { Initial } \\
\mathbf{p H}\end{array}$ & $\begin{array}{c}\mathbf{Q}_{\mathbf{p}} \\
(\mathbf{U} / \mathbf{L} / \mathbf{h})\end{array}$ & $\begin{array}{c}\mathbf{Y} \text { p/s } \\
(\mathbf{U} / \mathbf{g})\end{array}$ & $\begin{array}{c}\mathbf{Y} \mathbf{p} / \mathbf{x} \\
(\mathbf{U} / \mathbf{g})\end{array}$ & $\begin{array}{c}\mathbf{Q}_{\mathbf{s}} \\
(\mathbf{U} / \mathbf{g} / \mathbf{h})\end{array}$ \\
\hline 3 & 1975.8 & 0.36 & 27.56 & 8.99 \\
4 & 2364.8 & 0.41 & 38.96 & 7.5 \\
5 & 3897.6 & 0.53 & 32.40 & 7.8 \\
6 & 4654.8 & 0.64 & 42.85 & 4.96 \\
7 & 4065.9 & 0.57 & 42.48 & 8.23 \\
\hline
\end{tabular}

\section{Effect of Incubation temperature}

Different incubation temperatures such as 20, 25, 30,35 and $40^{\circ} \mathrm{C}$ were tested for optimum protease production by $R$. oryzae in submerged fermentation. Maximum product formation $\left(\mathrm{Q}_{\mathrm{p}}\right)$ and substrate utilization $\left(\mathrm{Q}_{\mathrm{s}}\right)$ was observed at $35^{\circ} \mathrm{C}$ as shown in Table 4. Further increase or decrease in incubation temperature beyond this reduced enzyme production. Different species of Rhizopus can produce maximum titer of protease at incubation temperature of $30^{\circ} \mathrm{C}$ (Sumantha et al. 2006; Irfan et al. 2011) and $33^{\circ} \mathrm{C}$ (Irfan et al. 2011). 
Table 4 - Effect of incubation temperature on alkaline protease production from Rhizopus oryzae in submerged fermentation.

\begin{tabular}{ccccc}
\hline $\begin{array}{c}\text { Temperature } \\
\left({ }^{\mathbf{0}} \mathbf{C}\right)\end{array}$ & $\begin{array}{c}\mathbf{Q}_{\mathbf{p}} \\
(\mathbf{U} / \mathbf{L} / \mathbf{h})\end{array}$ & $\begin{array}{c}\mathbf{Y}_{\mathbf{p} / \mathbf{s}} \\
(\mathbf{U} / \mathbf{g})\end{array}$ & $\begin{array}{c}\mathbf{Y}_{\mathbf{p} / \mathbf{x}} \\
(\mathbf{U} / \mathbf{g})\end{array}$ & $\begin{array}{c}\mathbf{Q}_{\mathbf{s}} \\
(\mathbf{U} / \mathbf{g} / \mathbf{h})\end{array}$ \\
\hline 20 & 2786.7 & 0.44 & 30.70 & 8.3 \\
25 & 3362.8 & 0.53 & 33.34 & 7.6 \\
30 & 3974.6 & 0.56 & 45.51 & 6.5 \\
35 & 4253.8 & 0.62 & 67.34 & 5.3 \\
40 & 3425.7 & 0.52 & 55.7 & 7.6 \\
\hline
\end{tabular}

\section{Effect of medium depth}

Different medium depths like $15 \mathrm{~mm}, 26 \mathrm{~mm}$ and $42.5 \mathrm{~mm}$ were used to check the production of protease from $R$. oryzae in submerged fermentation. Results (Table 5) showed that low or high medium depth significantly affected the protease production. Enzyme yield produced per substrate consumed or per cell biomass was achieved maximum with $26 \mathrm{~mm}$ of medium depth. Maximum substrate utilization was observed at medium depth of $26 \mathrm{~mm}$. Medium depth of 42.5 $\mathrm{mm}$ showed least protease yield, which might be due to poor penetration of air in the medium. Irfan et al. (2011) observed maximum carboxymethyl cellulase production using $25 \mathrm{~mL}$ medium volume in $250 \mathrm{~mL}$ flask.

Table 5 - Effect of medium depth on alkaline protease production from Rhizopus oryzae in submerged fermentation.

\begin{tabular}{ccccc}
\hline $\begin{array}{c}\text { Depth of } \\
\text { media }(\mathbf{m m})\end{array}$ & $\begin{array}{c}\mathbf{Q}_{\mathbf{p}} \\
(\mathbf{U} / \mathbf{L} / \mathbf{h})\end{array}$ & $\begin{array}{c}\mathbf{Y}_{\mathbf{p} / \mathbf{s}} \\
(\mathbf{U} / \mathbf{g})\end{array}$ & $\begin{array}{c}\mathbf{Y}_{\mathbf{p} / \mathbf{x}} \\
(\mathbf{U} / \mathbf{g})\end{array}$ & $\begin{array}{c}\mathbf{Q}_{\mathbf{s}} \\
(\mathbf{U} / \mathbf{g} / \mathbf{h})\end{array}$ \\
\hline 15 & 2698.5 & 0.46 & 37.3 & 6.04 \\
26 & 3642.5 & 0.61 & 60.5 & 5.96 \\
42.5 & 2295.6 & 0.36 & 45.0 & 8.10 \\
\hline
\end{tabular}

\section{Effect of inoculum size}

To check the proper inoculum size for maximum alkaline protease production, experiments were conducted by varying inoculum size from $1-5 \%$ in submerged fermentation. Results revealed (Table 6) that $2 \%$ inoculum level was optimum for maximum alkaline protease production. Further increase in inoculum size resulted decline in protease production. These results were in accordance with Niyonzima and More (2013) who also reported $2 \%$ inoculum size as optimum for maximum protease production by A. terrus in submerged fermentation. Radha et al. (2011) reported $4 \%$ inoculum size as the best for protease production by Aspergillus sp. under submerged fermentation.
Table 6 - Effect of inoculum size on alkaline protease production from Rhizopus oryzae in submerged fermentation.

\begin{tabular}{ccccc}
\hline $\begin{array}{c}\text { Inoculum size } \\
\mathbf{\%}(\mathbf{v} / \mathbf{v})\end{array}$ & $\begin{array}{c}\mathbf{Q}_{\mathbf{p}} \\
(\mathbf{U} / \mathbf{L} / \mathbf{h})\end{array}$ & $\begin{array}{c}\mathbf{Y}_{\mathbf{p} / \mathbf{s}} \\
(\mathbf{U} / \mathbf{g})\end{array}$ & $\begin{array}{c}\mathbf{Y}_{\mathbf{p} / \mathbf{x}} \\
(\mathbf{U} / \mathbf{g})\end{array}$ & $\begin{array}{c}\mathbf{Q}_{\mathbf{s}} \\
(\mathbf{U} / \mathbf{g} / \mathbf{h})\end{array}$ \\
\hline 1 & 2539.5 & 0.19 & 38.0 & 8.35 \\
2 & 3863.9 & 0.58 & 41.2 & 6.08 \\
3 & 3545.3 & 0.43 & 22.2 & 8.27 \\
4 & 3517.8 & 0.46 & 24.0 & 8.16 \\
5 & 3494.7 & 0.38 & 30.4 & 7.86 \\
\hline
\end{tabular}

\section{Purification of alkaline protease}

Alkaline protease was produced from $R$. oryzae by submerged fermentation at $35^{\circ} \mathrm{C}$ for $168 \mathrm{~h}$ of fermentation period using whey as substrate. Table 7 summarizes the purification steps of alkaline protease enzyme. The crude enzyme solution obtained from the fermentation broth was centrifuged and fractionated with ammonium sulphate $(30-80 \%)$. This showed that $70 \%$ ammonium sulphate saturation gave the highest enzyme activity. The enzyme suspension obtained after $70 \%$ ammonium sulphate saturation was dialyzed using Tris- $\mathrm{HCl}(0.05 \mathrm{M}, \mathrm{pH} 9.0)$ at $4^{\circ} \mathrm{C}$ for $24 \mathrm{~h}$ with three to four time replacement of the same buffer. The dialyzed enzyme solution was loaded on to a sephadex G-100 coulmn. The elution profile of the enzyme solution is shown in Figure 2. The elution profile showed that there was single peak. This peak gave enzyme yield of $37.25 \%$ with purification fold of 4.22 having specific activity of 77.45 . From purification, the specific activity was improved from 18.33 to 77.45 $\mathrm{U} / \mathrm{mg}$. The active fractions from this peak was pooled and lyophilized for further use. Yin et al. (2013) obtained purification fold of 6.6 with specific activity of $117.62 \mathrm{KU} / \mathrm{mg}$ using sephacryl S-200 HR column chromatography. Anandan et al. (2007) achieved purified fractions having specific activity of 905.7 using sephadex G-100 column chromatography. These variations in results might be due to the nature of protease, column used and microbial source. The purified alkaline protease after sephadex G-100 chromatography was further used to check the homogeneity by SDS-PAGE. Results showed (Fig. 3) a single band representing the purity of enzyme. The purified protease exhibited approximate molecular weight of 69.26 $\mathrm{kDa}$, calculated from plotting the molecular weight versus mobility. The molecular weight of protease of this strain was higher than other strains of Rhizopus sp. like $R$. oligosporus produced protease 
having molecular weight of $43 \mathrm{kDa}$ and $39 \mathrm{kDa}$ (Iqbal et al. 2011; Devi et al. 2011).

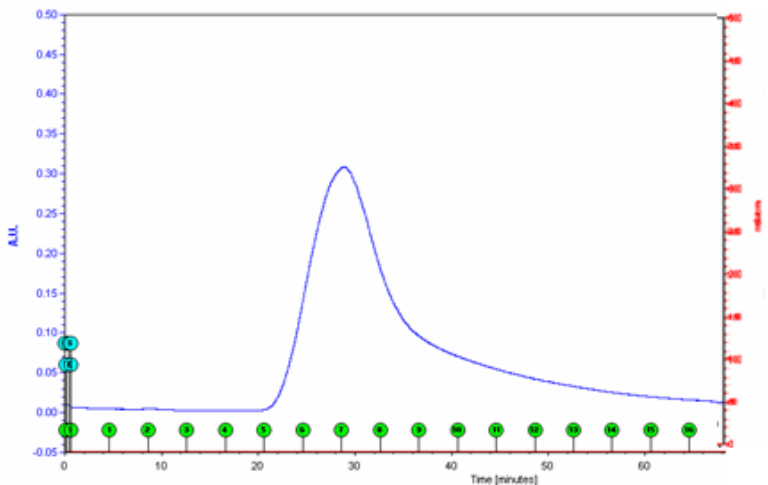

Figure 2 - Elution profile of alkaline protease through sephadex G-100 column chromatography.

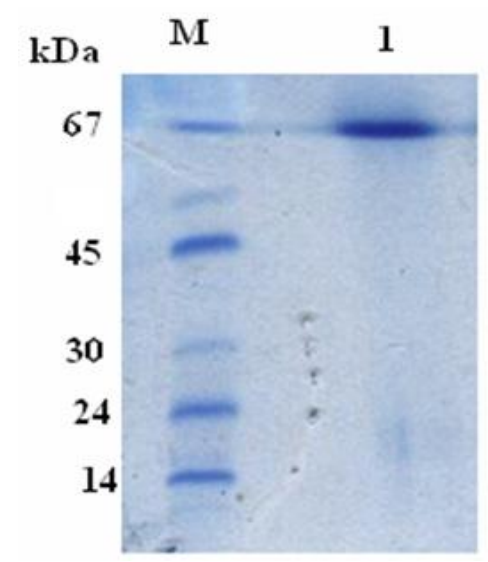

Figure 3 - SDS-PAGE of purified extracellular alkaline protease of Rhizopus oryzae. Standards were BSA $(67 \mathrm{kDa})$, ovalbumin $(45 \mathrm{kDa})$, carbonic anhydrase (30 kDa), trypsinogen (24 kDa), and $\alpha$ - lactalbumin (14 kDa).

\section{Characterization of alkaline protease Effect of pH}

To study the effect of $\mathrm{pH}$ on protease activity, the purified protease was incubated in different $\mathrm{pH}$ (4.0-11.0) buffers for $1 \mathrm{~h}$ at room temperature. Results (Fig.4) showed that the enzyme activity was increased with increase of $\mathrm{pH}$. At $\mathrm{pH} 4.0$, the enzyme activity was $118.09 \mathrm{PU} / \mathrm{mL}$ and the peak activity was observed at $\mathrm{pH}$ 9.0, which was 674.67 $\mathrm{PU} / \mathrm{mL}$. As the $\mathrm{pH}$ was increased to 11.0 , the enzyme activity was reduced to $191.26 \mathrm{PU} / \mathrm{mL}$. $\mathrm{pH}$ stability analysis revealed that the enzyme was stable in $\mathrm{pH}$ range from 7.0 to 9.0. These results showed that the enzyme was optimally active in alkaline condition. These results were supported by other researchers who reported that the protease produced by $R$. oryzae was alkaline in nature (Banjeer et al.1992; Gull et al. 2012).

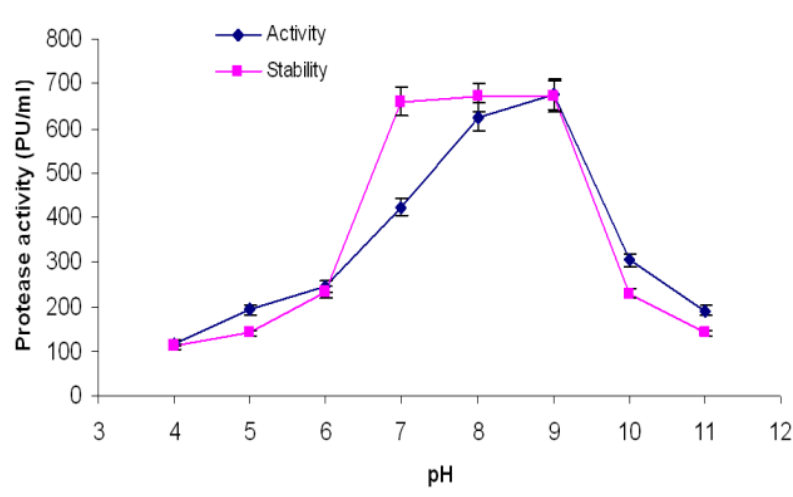

Figure 4 - Effect of $\mathrm{pH}$ on activity and stability of alkaline protease produced from Rhizopus oryzae in submerge fermentation.

\section{Effect of temperature on protease activity}

The optimum temperature of alkaline protease was checked by incubation the reaction mixtures at different temperatures ranging from $20-60^{\circ} \mathrm{C}$. Results (Fig. 5) showed that protease activity was increased with increase in temperature and optimum activity was observed at $40^{\circ} \mathrm{C}$. Further increase in temperature beyond this resulted decline in enzyme activity. Thermostability analysis revealed that the alkaline protease was stable up to $40^{\circ} \mathrm{C}$ with incubation time of $6 \mathrm{~h}$. The results of this study were in accordance with previous reports (Coral et al. 2003; Olajyuigbe and Ajele 2005; Hussain et al. 2010; Gul et al. 2012).

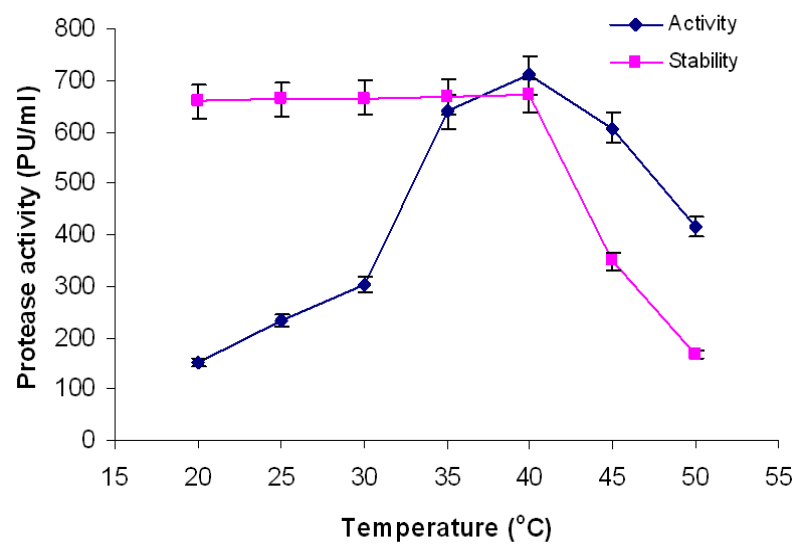

Figure 5 - Effect of temperature on alkaline protease activity and stability. 
Protease produced from $R$. oligosporus was optimally active at $50^{\circ} \mathrm{C}$ (Iqbal et al. 2011). These findings indicated that alkaline proteases produced from fungi were not thermophilic but mostly were mesophilic in nature.

\section{Effect of time of incubation on protease activity}

Alkaline protease activity was checked by incubating the reaction mixtures at different time period, ranging from 5-30 $\mathrm{min}$. The optimum enzyme activity was observed at $10 \mathrm{~min}$ of incubation time as shown in Figure 6. Further increase in incubation time resulted decline in enzyme activity. The enzyme activity did not change from 20 to $30 \mathrm{~min}$ of incubation time. Gul et al. (2012) reported the optimum time of incubation for maximum protease activity was 20 min.

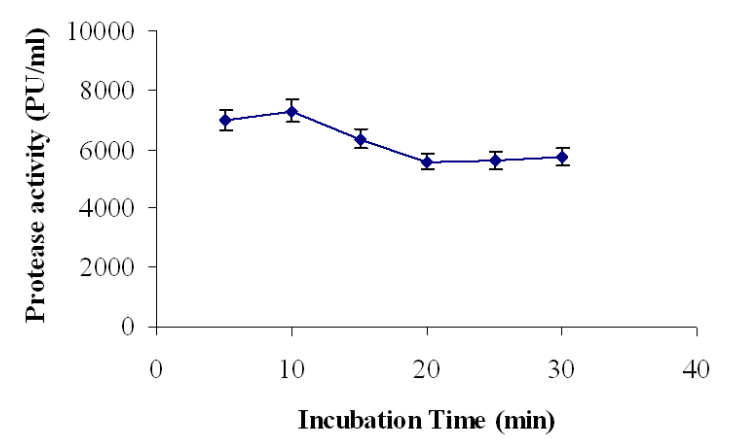

Figure 6 - Effect of incubation time on alkaline protease activity.

\section{Effect of metals}

To check the activation or inhibition of alkaline protease activity, different metals were used with concentration of $5 \mathrm{mM}$. Results (Fig. 7) demonstrated that the enzyme was not significantly affected by the metals in term of activation. This meant that the enzyme was not metaloproteases. Some metals like $\mathrm{Hg}^{2+}, \mathrm{Fe}^{2+}$ and $\mathrm{Zn}^{2+}$ were strong inhibitors of alkaline protease activity. These findings were very similar to that of Anandan et al. (2007) who also reported that $\mathrm{Hg}^{2+}$ was strong inhibitor of alkaline protease activity while $\mathrm{Ca}^{2+}$ and $\mathrm{Mg}^{2+}$ had slight effect on enzyme activation. Some studies reported that $\mathrm{Zn}^{2+}$ acted as inhibitor for cysteine proteases (Damare et al. 2006; Gaur et al. 2008).

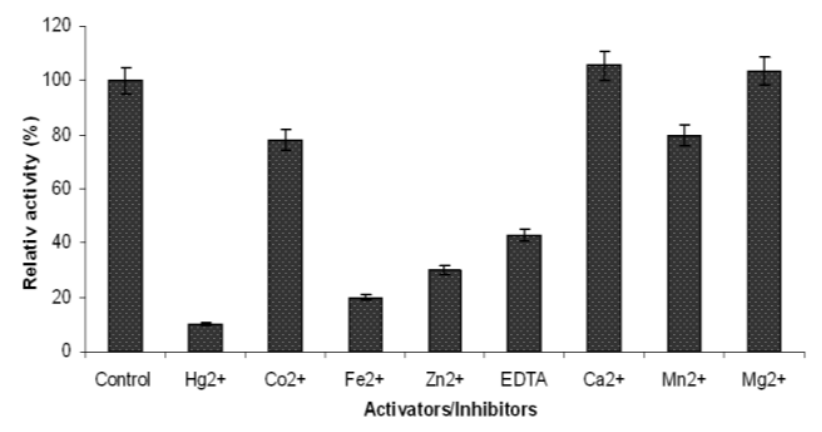

Figure 7 - Effect of metal ions on alkaline protease activity produced from Rhizopus oryzae in submerge fermentation.

\section{Enzyme kinetics}

By using casein as a substrate, the purified alkaline protease exhibited $K_{m}, K_{c a t}$ and $V_{\max }$ value of 7.0 $\mathrm{mg} / \mathrm{mL}, \quad 3.8 \times 10^{2} \mathrm{~S}^{-1}$ and $54.30 \mu \mathrm{mol} / \mathrm{min}$ calculated by Line-weaver Burk plot (Fig. 8). The catalytic efficiency $\left(\mathrm{K}_{\text {cat }} / \mathrm{K}_{\mathrm{m}}\right)$ of this enzyme was $54.28 \mathrm{~s}^{-1} \mathrm{mg}^{-1} . \mathrm{mL}$. Siala et al. (2009) reported $K_{m}$ and $V_{\max }$ value of $1.02 \mathrm{mM}$ and $2.2 \mu \mathrm{mol} / \mathrm{min}$ for acidic protease from $A$. niger $\mathrm{I} 1$ using casine as a substrate. Yin et al. (2013) purified and characterized acidic protease from $A$. oryzae BCRC 30118 had $K_{m}, V_{\max }, K_{\text {cat }}$ and $\mathrm{K}_{\text {cat }} / \mathrm{K}_{\mathrm{m}}$ values of $0.12 \mathrm{mM}, 14.29 \mu \mathrm{mol} / \mathrm{min}, 14.55 \mathrm{sec}^{-1}$ and $125.80\left(\mathrm{sec}^{-1} \mathrm{mM}^{-1}\right)$ for the hydrolysis of hemoglobin, respectively. Extracellular alkaline serine protease isolated from Engyodontium album BTMFS10 had $K_{m}, V_{\max }$, and $K_{\text {cat }}$ of the enzyme were $4.727910^{-2} \mathrm{mg} / \mathrm{mL}, 394.68 \mathrm{U}$, and 4.21759 $10^{-2} \mathrm{~s}^{-1}$, respectively (Chellppan et al. 2011).

\section{Detergent Compatibility}

A good protease must be stable and active in the detergents so that the efficiencies of enzyme can be achieved. To exploit the industrial applications of this enzyme, the enzyme was used to check the detergent compatibility (Fig. 9). The enzyme showed good compatibility with locally available detergents (Surf Excel and Bright Total) in the presence of $5 \mathrm{mM} \mathrm{CaCl} 2$.The enzyme retained $81.01 \%$ stability after $10 \mathrm{~min}$ of incubation at $40^{\circ} \mathrm{C}$; even after 120 min of incubation it retained $65.65 \%$ activity with Surf excel and 54\% activity at $40^{\circ} \mathrm{C}$. Sindhu et al. (2009) reported alkaline protease from $P$. godlewskii SBSS, which had $100 \%$ stability with detergents like surf and henko. Adinarayana (2003) reported $16 \%$ protease 
activity with revel, $11.4 \%$ in Arial and $6.6 \%$ activity in wheel detergents. The present protease retained more than $60 \%$ activity in detergents.
Hence, the enzyme could be useful to be used in the detergents at moderate temperatures and alkaline $\mathrm{pH}$ range.

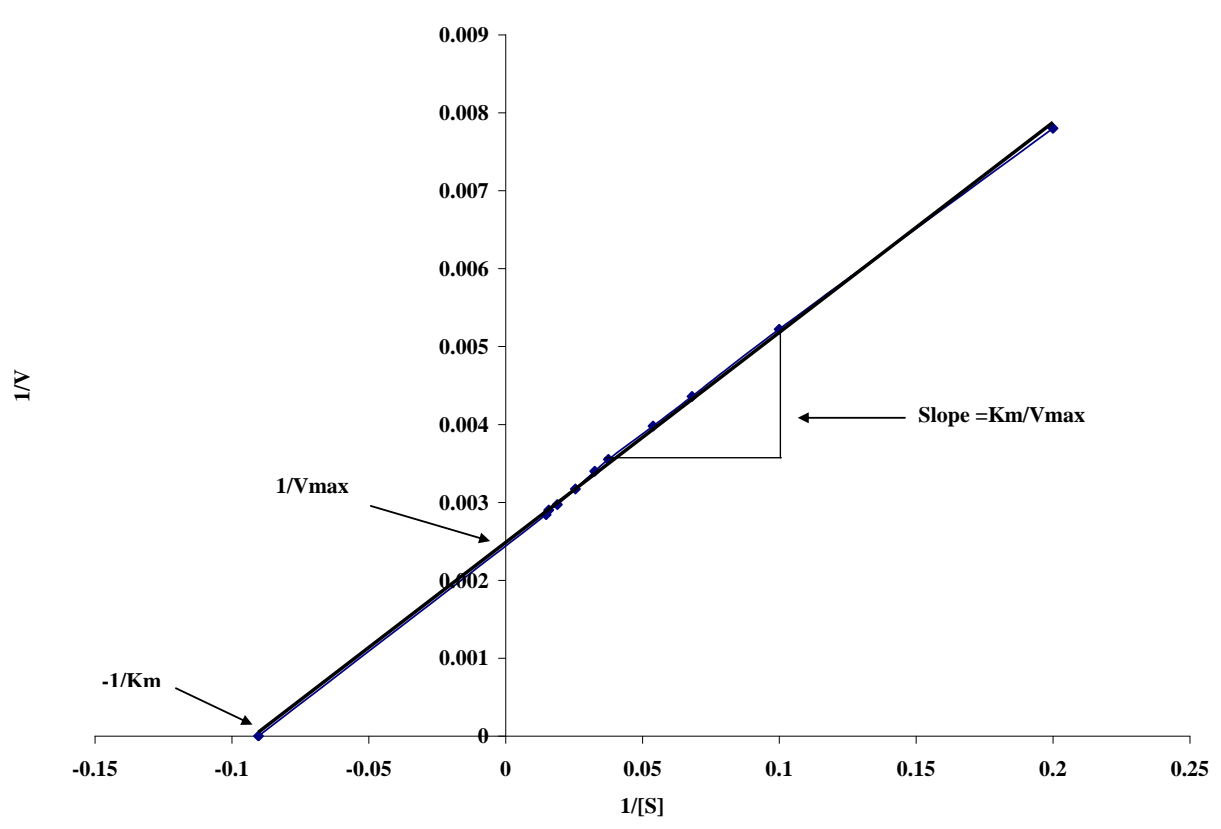

Figure 8 - Line-Weaver Burk plot of alkaline protease for estimation of kinetic constants.
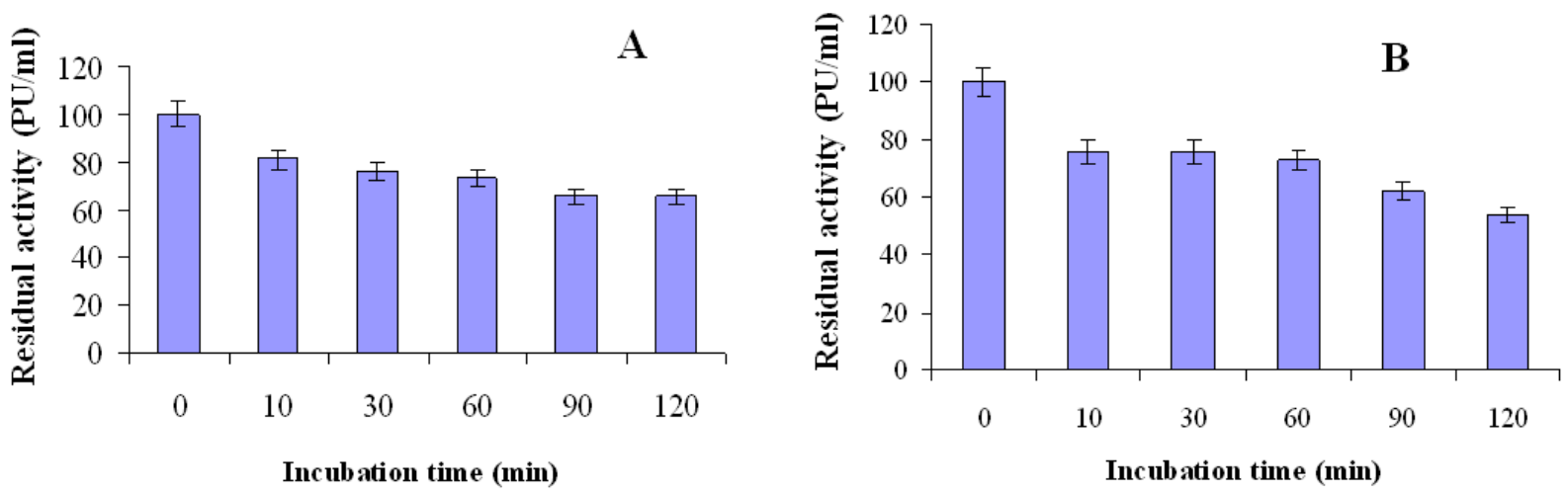

Figure 9 - Detergent compatibility of alkaline protease (A) Surf Excel (B) Bright total.

\section{CONCLUSIONS}

Proteases are always very important in every field of life. Tremendous research work has been done in this field of science for enzyme production and still is going on. The exploration of new cost effective process for enzyme production by exploiting industrial waste is the basic need of today in the current competitive enzyme market. In the present work, whey a dairy industry waste, was used as a substrate for alkaline protease production by $R$. oryzae. The optimum alkaline $\mathrm{pH}$ (9.0), reasonable activity at high temperature up to $55^{\circ} \mathrm{C}$ and good detergent compatibility characteristics make this alkaline protease a promising candidate to be used in detergent industry. The utilization of cheap substrate for protease production and high purification fold with easy protocols could make this enzyme economically feasible. 


\section{ACKNOWLEDGMENTS}

The authors are thankful to PCSIR Laboratories Complex, Lahore for providing laboratory facilities required to accomplish this research work.

\section{REFERENCES}

Adinarayana K. Purification and characterization of thermostable serine alkaline protease from a newly isolated Bacillus subtilis. PE-11. AAPS Pharma Sci Technol. 2003; 56: 245-250.

Aguilar CN, Favela-Torres E, Viniegra-Gonzalez, Augur C. Culture conditions dictate protease and tannase production in submerged and solid-state cultures of Aspergillus niger Aa-20. Appl Biochem Biotechnol. 2002; 102-103: 407-414.

Aikat K, Bhattacharyya BC. Protease extraction in solid state fermentation of wheat bran by a local strain of Rhizopus oryzae and growth studies by the soft gel technique. Proc Biochem. 2000; 35: 907-914.

Anandan D, Marmer WN, Dudley RL. Isolation, characterization and optimization of culture parameters for production of an alkaline protease isolated from Aspergillus tamari. J Ind Microbiol Biotechnol. 2007; 34: 339-347

AOAC Official Methods of Analysis $2005.15^{\text {th }}$ Edition, Association of Official Analytical Chemists. Washington DC.

Ashour SA, El-shora HM, Metwally M, Habib SA. Fungal fermentation of whey incorporated with certain supplements for the production of proteases. Microbiol Bios. 1996; 86: 59-69.

Banarjee R, Bhattacharyya BC. Purification and characterization of protease from a newly isolated Rhizopus oryzae. Bioproc Biosys Engin. 1992; 7: 369-374.

Chellappan S, Jasmin C, Basheer SM, Kishore A, Elyas KK, Bhat SG, Chandrasekaran M. Characterization of an extracellular alkaline serine protease from marine Engyodontium album BTMFS10. J Ind Microbiol Biotechnol. 2011; 38: 743-752.

Coral G, Arikan B, Ünaldi MN. Güvenmez, H. Thermostable alkaline protease produced by an Aspergillus niger strain. Annals Microbiol. 2003; 53: 491-498.

Damare S, Raghukumar C, Muraleedharan UD. Raghukumar, S. Deep sea fungi as a source of alkaline and cold resistant proteases. Enz Microbial Technol. 2006; 39: 172-181.

Devi PR, Raghavan PV, Vasudheven I, Joshua L, VijayaKumar M. Purification and Characterization of Protease from Rhizopus oligosporus. Int $J$ Biol Technol. 2011; 2: 46-49.
Dubois M, Gilles KA, Hamilton JK, Rebers PA, Smith F. Colorimetric method for determination of sugars and related substances. Anal Chem. 1956; 28: 350356.

Gaur A, Wadhwa S. Alkaline protease from senesced leaves of invasive weed Lantana camara. Afr $J$ Biotechnol. 2008; 7: 4602-4607.

Gul A, Baig S, Naz M, Nadeem M. Efficient utilization of dairy industry waste for hyper production and characterization of a novel cysteine protease. Pak J Zool. 2012; 44: 713-721.

Haq I, Mukhtar H. Biosynthesis of proteases by Rhizopus oligosporus $\mathrm{IHS}_{13}$ in low-cost medium by solid-state fermentation. J Basic Microbiol. 2004; 44: 280-287.

Hussain AA, Manan H, Zubair, Mirza B. Purification and characterization of alkaline proteases from Aspergillus terrus. J chem Soc Pak. 2010; 32:497504.

Iqbal HMN, Ahmad I, Khan MA. Partial characterization of purified protease Rhizopus oligosporus using produced from by products of oil industry. World Appl Sci J. 2011; 13: 600-605.

Irfan M, Irfan U, Razzaq Z, Syed Q, Nadeem M. Utilization of agricultural wastes as a substrate for Carboxymethyl cellulase production from Aspergillus niger in submerged fermentation. Int J Agro Vet Med Sci. 2011; 5: 464-471.

Irfan M, Rauf A, Syed Q, Nadeem M, Baig S. Exploitation of Different Agro-residues for Acid protease Production by Rhizopus sp. in Koji Fermentation. Int J Agro Vet Med Sci. 2011; 5: 43-52.

Joo HS, Kumar CG, Park GC, Paik SR, Chang CS. Oxidant and SDS-stable alkaline protease from Bacillus clausii I-52: Production and some properties. J Appl Microbiol. 2003; 95: 267-272.

Kelly CT, Fogarty WM. Microbial alkaline enzymes. Process Biochem. 1976; 11:3-9.

Kuntz M. Crystalline soyabean trypsin inhibitor. J Gen Physiol. 1947; 30: 291-301.

Laemmli UK. Cleavage of structural proteins during the assembly of the head of bacteriaophage T4. Nature. 1970; 227: 680-685.

Lowry OH, Rosebrough NJ, Farr AL, Randall JR. Protein measurements with the follin phenol reagent. J Biol Chem. 1951; 193: 265-275.

Moon SH, Parulekar SJ. A parametric study of protease production in batch and fed-batch cultures of Bacillus firmus. Biotechnol Bioeng. 1991; 37: 467-483.

Nadeem M, Qazi JI, Syed Q, Baig S. Optimization of Process Parameters for Alkaline Protease Production by Bacillus licheniformis N-2 and Kinetics Studies in Batch Fermentation. Turk J Biol. 2008; 32: 243-251.

Nadeem M, Qazi JI, Syed Q, Gulsher M. Purification and characterization of an alkaline protease from Bacillus licheniformis UV-9 for detergent formulations. Songklanakari J Sci Technol. 2013; 35: 187-195. 
Niyonzima FN, More SS. Screening and optimization of cultural parameters for an alkaline protease production by Aspergillus terreus gr. under submerged fermentation. Int J Pharm Bio Sci. 2013; 4: 1016-1028.

Olajyuigbe FM, Ajele JO. Production dynamics of extracellular protease from Bacillus species. Afr $J$ Biotechnol. 2005; 4: 776-779.

Omole JO, Ighodaro OM, Makanjuola OM. Proximate Composition of Whey from South West Nigeria. Adva Biores. 2012; 3: 14-16.

Pandey A, Selvakumar P, Soccal CR, Nigam P. Solid state fermentation for the production of industrial enzymes. Curr Sci. 1999; 77: 149-162.

Papagiani M, Joshi N, Moo-Young M. Comparative study on extra cellular protease secretion and glucoamylase production by free and immobilized Aspergillus induced reactive oxygen species improve production from Aspergillus niger cultivation. J Ind Microbiol Biotechnol. 2002; 29: 259-263.

Radha S, Nithya VJ, Himakiran R, Sridevi A, Prasad NBL, Narasimha G. Production and optimization of acid protease by Aspergillus spp. under submerged fermentation. Arch Appl Sci Res. 2011; 3: 155-163.

Rao MB, Tanksale AM, Ghatge MS, Deshpande VV. Molecular and biotechnological aspects of microbial proteases. Microbiol Mol Biol Rev.1998; 62: 597-635.

Saeki K, Ozaki K, Kobayashi T, Ito S. Detergent alkaline proteases, enzymatic properties, genes, and crystal structures. J Biosci Bioeng. 2007; 103: 501508.
Siala R, Sellami-Kamoun A, Hajji M, Abid I, Gharsallah N, Nasri M. Extracellular acid protease from Aspergillus niger II, purification and characterization. Afr J Biotechnol. 2009; 8: 45824589.

Sindhu R, Suprabha GN, Shashidhar S. Optimization of process parameters for the production of alkaline protease from Penicillium godlewskii SBSS 25 and its application in detergent industry. Afr $J$ Microbiol Res. 2009; 3: 515-522.

Sumantha A, Deepa P, Sandhya C, Szakacs G, Soccol CR, Pandey A. Rice Bran as a Substrate for Proteolytic Enzyme Production. Braz Arch Biol Technol. 2006; 49: 843-851.

Talabardon M, Yang ST. Production of GFP and glucoamylase by recombinant Aspergillus niger. Biotechnol Prog. 2005; 21:1389-400.

Yin L, Chou Y, Jiang S. Purification and Characterization of acidic protease from Aspergillus oryzae BCRC 30118. J Marine Sci Technol. 2013; 21: 105-110. 